Al Qalam: Jurnal Ilmiah Keagamaan dan Kemasyarakatan

Vol. 13, No. 1, 2019

P-ISSN: 1907-4174; E-ISSN: 2621-0681

\title{
INOVASI KURIKULUM DI MADRASAH ALIYAH
}

\author{
Oleh: \\ Muhammad Rasyidi \\ Guru, UPTD Dinas Pendidikan SMP Negeri 7 \\ Kalimantan Timur \\ Email : muhammadrasyidi469@yahoo.com
}

\begin{abstract}
Abstrak
Penelitian ini bertujuan untuk: 1) Mengetahui perencanaan inovasi kurikulum di Madrasah Aliyah (MA) Darul Ihsan Samarinda, 2) Mengetahui bentuk-bentuk inovasi kurikulum di Madrasah Aliyah (MA) Darul Ihsan Samarinda. 3) Mengetahui faktor yang mendukung pelaksanaan inovasi kurikulum di Madrasah Aliyah (MA) Darul Ihsan Samarinda. 4) Mengetahui faktor yang menghambat pelaksanaan inovasi kurikulum di Madrasah Aliyah (MA) Darul Ihsan Samarinda. Jenis penelitian ini adalah deskriptif analitis. Pendekatan yang digunakan yaitu deskriptif kualitatif. Hasil dari penelitian ini adalah bahwa inovasi kurikulum di Madrasah Aliyah Darul Ihsan Samarinda yaitu berupa: a) mengembangkan rencana inovasi kurikulum dengan segenap komponen madrasah yang ikut berpartisipasi, landasan inovasi kurikulumnya berupa budaya setempat dan kemajuan ilmu pengetahuan dan teknologi, b) inovasi tujuan kurikulum yang memadukan tujuan madrasah dan tujuan pemerintah/nasional, c) inovasi bahan ajar yang menyesuaikan visi dan misi sekolah sehingga dapat dicanangkan motode pembelajaran yang kontekstual, d) pemanfaatan media seperti OHP proyektor saat mengajar, laboratorium komputer pada saat pelajaran praktek computer dan lainnya, e) penyusunan sistem evaluasi yang disesuaikan dengan program madrasah dan pemerintah, f) inovasi ekstrakurikuler atau pengembangan diri berupa maulid al- habsyi, rebana, seni kaligrafi, Arabic club, English club, bimbingan baca Alquran, TIK, dan kelompok olahraga, g) inovasi muatan lokal yang diprogramkan agar sesuai dengan keunggulan
\end{abstract}


madrasah berupa semua pelajaran pondok seperti: ilmu fiqih, tauhid, hadits, akhlak, faraidh, tafsir, nahwu shorf, tarikh, khot, ushul fiqh, dan pelajaran kitab kuning. Sedangkan Faktor-faktor yang mempengaruhi yaitu: a) faktor pendukung diantaranya faktor guru (SDM), faktor media, faktor sarana dan prasarana, faktor kemajuan ilmu pengetahuan dan teknologi, sedangkan b) faktor penghambat diantaranya, kurang tersedianya anggaran yang memadai dan evaluasi atau penilaian kognitif berupa Ujian Nasional yang membuat sulit madrasah karena harus mengejar target kelulusan.

Kata Kunci : Inovasi, kurikulum dan madrasah

\section{A. Pendahuluan}

Kurikulum sebagai salah satu komponen sekolah juga mengalami perubahan dan pembaharuan yang harus disesuaikan dengan tuntutan masyarakat, sehingga sekolah harus mampu menyesuaikan diri dengan keadaan tersebut. ${ }^{1}$ Ini dikarenakan kurikulum merupakan alat yang sangat penting dalam keberhasilan suatu pendidikan, tanpa adanya kurikulum yang baik dan tepat, maka akan sulit dalam mencapai tujuan dan sasaran pendidikan yang dicitacitakan. Kurikulum juga memegang kedudukan kunci dalam pendidikan, sebab berkaitan dengan penentuan arah, isi dan proses pendidikan, yang pada akhirnya menentukan macam dan kualifikasi lulusan suatu lembaga pendidikan. Oleh karena itu, kurikulum harus dikelola dan dikembangkan sesuai dengan situasi dan kondisi dimana sekolah itu berada.

Diperlukan suatu rancangan yang matang dalam pengembangan kurikulum. Dalam kurikulum terintegrasi filsafat, nilai-nilai, pengetahuan dan perbuatan pendidikan. Kurikulum disusun oleh para ahli pendidikan/ahli kurikulum, ahli bidang ilmu, pendidik, pejabat pendidikan, pengusaha serta unsur masyarakat lainnya. Rancangan ini disusun dengan maksud memberi pedoman kepada para pelaksana pendidikan, dalam proses pembimbingan perkembangan siswa, mencapai tujuan yang dicita-citakan oleh siswa sendiri, keluarga dan masyarakat. Itulah rencana pengembangan kurikulum yang

${ }^{1}$ Abdullah Idi, Pengembangan Kurikulum Teori dan Praktek, (Jakarta: Gaya Media,1999), h. 3. 
menjadi tujuan. Banyak yang harus digali dan diformulasikan dalam pengembangan kurikulum. Tentunya kurikulum yang sudah terlaksana juga akan memberikan pengalaman untuk pengembangan kurikulum ke depan.

Menurut Nana Syaodih Sukmadinata dalam bukunya "Pengembangan Kurikulum: Teori dan Praktek" ada 8 model pengembangan kurikulum yang telah menjadi acuan yaitu: the administrative model, the grass roots model, beauchamp's system, the demonstration model, Taba's inverted model, Roger's in terpersonal relations model, the systematic action research model dan emerging technical model. ${ }^{2}$

Dengan banyaknya model dalam pengembangan kurikulum ini memungkinkan untuk sekolah berinovasi untuk menggunakan salah satu atau dikolaborasikan sehingga mencapai tujuan sekolah. Adapun dalam pengembangan kurikulum untuk mencapai tujuan yang telah ditetapkan, salah satu unsur yang harus dilakukan adalah adanya inovasi yang matang dari sekolah dan pelaksanaannya harus ditopang oleh manajemen yang tepat.

Menurut Udin Syaefudin Sa'ud mendefinisikan inovasi yaitu suatu hal yang baru atau segala sesuatu hal yang baru atau pembaharuan artinya hasil kreasi manusia. ${ }^{3}$ Inovasi dapat juga dikatakan discovery merupakan suatu ide, barang, kejadian atau metode yang dirasakan atau diamati sebagai suatu hal yang baru untuk mencapa tujuan tertentu atau untuk memecahkan suatu masalah tertentu. Dengan demikian dari beberapa pendapat di atas mengenai inovasi, artinya dapat juga dikatakan sesuatu yang sudah ada kemudian dikolaborasikan dengan yang lain sehingga menimbulkan sesuatu yang baru. Begitu juga dengan pengembangan kurikulum dengan beberapa model di atas. Inilah yang dikatakan inovasi pengembangan kurikulum yang dilaksanakan oleh sekolah.

Setidaknya dalam inovasi pengembangan kurikulum yang harus

${ }^{2}$ Nana Syaodih Sukmadinata, Pengembangan Kurikulum Teori dan Praktek, (Bandung: PT. Remaja Rosdakarya, 2013), Cet. XVI, h. 161.

${ }^{3}$ Udin Syaefudin Sa'ud, Inovasi Pendidikan, (Bandung: Alfabeta, 2011), Cet IV, h. 3 . 
dipersiapkan adalah komponennya, para pengembang seperti administrator pendidikan, ahli pendidikan, ahli kurikulum, guru-guru, dan yang penting lagi anggaran biaya yang dikeluarkan dalam inovasi pengembangan kurikulum.

Hal ini senada dengan apa yang telah dilaksanakan oleh berbagai sekolah dalam mencapai tujuan pendidikan. Lembaga sekolah berusaha melaksanakan kurikulum yang telah ditentukan oleh pemerintah dan para ahli kurikulum agar terlaksana dengan baik dan terencana, sehingga efeknya adalah kualitas pendidikan di sekolah tersebut menjadi meningkat. Sekolah umum biasanya menggunakan kurikulum yang sudah diisyaratkan oleh pemerintah untuk diimplementasikan. Namun ada juga sekolah dengan otonominya sendiri tidak sepenuhnya melaksanakan kurikulum dari pemerintah. Pandangan mereka kurikulum yang telah ada baik kurikulum KTSP atau KBK atau kurikulum 2013 sekarang umumnya adalah untuk kompetensi kognitif saja, namun untuk keahlian lain ternyata belum maksimal.

Di antara sekolah yang tidak sepenuhnya melaksanakan biasanya disekolah oleh pihak swasta atau yang mempunyai yayasan. Sehingga mendirikan sekolah dengan biaya dan aturan sendiri. Seperti pendirian Pondok Pesantren dan Madrasah. Awalnya pihak pondok melaksanakan kurikulum dengan kurikulum sendiri yang dinamakan kurikulum pondok. Namun dengan adanya kebutuhan siswa dan manajemen sekolah untuk meningkatkan kualitas pendidikan, mau tidak mau memadukan kurikulum pondok dengan kurikulum Nasional dari pemerintah. Inilah yang menurut peneliti, bentuk dari inovasi pengembangan kurikulum.

Salah satunya yang melaksakan adalah Pondok Pesantren yang diberi nama Darul Ihsan. Pondok ini memiliki 2 madrasah yaitu Madrasah Tsanawiyah dan Madrasah Aliyah. Madrasah Aliyah Darul Ihsan berdiri pada tahun 1983. Pondok tersebut merupakan sebuah lembaga pendidikan formal yang bernafaskan Islam, sehingga pondok ini mempunyai peranan penting dalam pembentukan manusia muslim yang bertaqwa dan berpengetahuan.

Sejak pertama kali kiprahnya terhadap pendidikan yayasan pondok 
pesantren Darul Ihsan ini menggunakan metode Pondok Pesantren pada umumnya. Metode pesantren yang digunakan dapat dilihat dengan mata pelajaran yang diajarkan kepada seluruh siswa yang ada di pondok ini, seperti adanya pelajaran kitab-kitab kuno Islam (kitab kuning).

Adapun mata pelajaran yang diajarkan sudah terbagi menjadi dua bagian, yaitu pelajaran umum dan khusus. Sehingga sekarang ini mereka mempunyai kurikulum pondok dan kurikulum Depag. Untuk kurikulum pondok, mereka masih menggunakan beberapa kitab yang bertulisan arab yang didalamnya terdiri dari beberapa pokok mata pelajaran. Namun mereka juga tetap menggunakan buku-buku yang sesuai dengan kurikulum Depag. Selain itu, Madrasah ini juga tidak menapikan pelajaran-pelajaran umum seperti Bahasa Indonesia, Bahasa Inggris, Fisika, dan Ilmu-ilmu Sosial. Madrasah inipun telah mempunyai dua jurusan, yaitu jurusan IPS dan jurusan IPA.

Dengan inovasi kurikulum yang telah dikembangkan oleh pihak Pondok Pesantren Madrasah Aliyah Darul Ihsan, para siswa berhak dengan mendapatkan 2 ijazah sekaligus ketika lulus, sehingga memiliki kualitas tidak hanya akademik secara umum tapi juga memiliki kemampuan tidak seperti sekolah lain. Inilah yang menjadi inovasi pengembangan kurikulum madrasah yang melahirkan out put siswa handal dalam kualitas pendidikan.

\section{B. Metode Penelitian}

Artikel ini menggunakan jenis penelitian deskriptif analitis. Dalam penelitian kualitatif manusia adalah sebagai sumber data utama dan hasil penelitiannya berupa kata-kata atau pernyataan yang sesuai dengan keadaan sebenarnya (alamiah). Untuk itu, desain penelitian ini dikembangkan secara terbuka dari berbagai perubahan yang diperlukan sesuai dengan kondisi lapangan. ${ }^{4}$ Hal ini penting untuk dijelaskan, mengingat penelitian kualitatif merupakan penelitian yang didesain dalam kondisi dan situasi alamiah

4 Nurul Zuriah, Metodologi Penelitian Sosial Dan Pendidikan; Teori Dan Aplikasi, (Jakarta: Bumi Aksara, 2006), h. 91. 
(naturalistic) sehingga dapat ditemukan kebenaran dalam bentuk yang semurnimurninya tanpa mengalami distorsi yang disebabkan oleh instrumen dan desain penelitian, karena instrumen dan desain penelitian cenderung mengkotakkotakkan manusia dalam kerangka konsepsi yang kaku. Sasaran penelitian ini adalah perilaku atau tindakan-tindakan, kebijakan-kebijakan yang dipergunakan dan diambil dalam rangka pengembangan kurikulum di Madrasah Aliyah (MA) Darul Ihsan Samarinda.

Sedangkan pendekatan yang digunakan yaitu pendekatan deskriptif kualitatif. Peneliti berkeyakinan bahwa dengan pendekatan ini bisa lebih kaya. Penelitian kualitatif-deskriptif dimaksudkan untuk pengukuran yang cermat terhadap fenomena sosial tertentu. ${ }^{5}$ Hal ini tentunya yang perlu dicermati adalah pelaksanaan kurikulum yang sudah dijalankan oleh Madrasah Aliyah Darul Ihsan Samarinda.

Hal ini sesuai dengan pendapat Denzin dan Lincoln yang mengatakan bahwa penelitian kualitatif adalah penelitian yang menggunakan latar alamiah, dengan maksud menafsirkan fenomena yang terjadi dan dilakukan dengan jalan melibatkan berbagai metode yang ada.

Menurut Muhajir penelitian kualitatif setidak-tidaknya mengakui empat kebenaran, yaitu: kebenaran empirik, empirik logik-teoritik, empirik etik dan empirik transendental. Kemampuan dan pemaknaan manusia atas indikasi empirik manusia menjadi mampu mengenal keempat kebenaran tersebut. ${ }^{6}$

\section{Konsep Inovasi Kurikulum}

Inovasi merupakan berasal dari "innovation" yang diterjemahkan dengan arti segala hal yang baru atau pembaharuan. ${ }^{7}$ Menurut Everett $\mathrm{M}$. Rogers yang dikutip oleh Udin Syaefudin, mendefisisikan bahwa inovasi adalah

5 Masri Singarimbun dan Sofian Effendi (Ed), Metode Penelitian Survei, (Jakarta: LP3ES, 1995), h. 4.

${ }^{6}$ Noeng Muhajir, Metodologi Penelitian Kualitatif, (Yogyakarta: Rake Sarasin, 1988), h. 19.

${ }^{7}$ Udin Syaefudin Sa'ud, Inovasi Pendidikan, (Bandung: Alfabeta, 2011), h. 2. 
suatu ide, gagasan, kejadian, metode yang diamati sebagai suatu yang baru bagi seseorang atau sekelompok orang, baik berupa hasil invensi atau diskoveri yang diadakan untuk mencapai tujuan tertentu. ${ }^{8}$

Dalam proses pembelajaran diperlukan suatu perhitungan tentang kondisi dan situasi, dimana proses tersebut berlangsung dalam jangka panjang. Dalam perhitungan tersebut, maka proses pengembangan kurikulum akan lebih terarah kepada tujuan yang hendak dicapai karena segala sesuatunya telah dipertimbangkan secara matang.

Itulah sebabnya, lembaga pendidikan memerlukan inovasi yang menyangkut pada masalah bagaimana mengembangkan kurikulum dengan melihat situasi dan kondisi yang ada, dan juga bagaimana agar proses tersebut tidak terdapat hambatan serta ganguan baik internal maupun eksternal yang menyangkut kelembagaan maupun lingkungan sekitarnya.

Dalam sebuah lembaga pendidikan terutama lembaga Perguruan Tinggi yang akan menghasilkan calon-calon pendidik, maka perlu diperhatikan kurikulum yang disajikan oleh lembaga tersebut. Guna mencapai keberhasilan pendidikan tujuan pendidikan baik pendidikan nasional maupun tujuan pendidikan agama.

Dalam hal ini, penulis memberikan pengertian kurikulum yang mudah dipahami yaitu : seperangkat rencana materi atau bahan yang diberikan dalam suatu kegiatan belajar mengajar, dan tidak terlepas dari pengetahuan, keterampilan dan sikap sesuai dengan tujuan pendidikan tertentu. ${ }^{9}$ Dalam pendidikan Islam juga menjelaskan pengertian kurikulum yang berasal dari kata manhaj yang mempunyai arti jalan yang terang. ${ }^{10}$ Dalam kurikulum ini menjelaskan bahwa setiap pendidik memberikan jalan terang bagi peserta didik untuk mendapatkan pengetahuan, keterampilan dan sikap yaitu melalui proses

\footnotetext{
${ }^{8}$ Udin Syaefudin Sa'ud, Inovasi..., h. 29.

${ }^{9}$ Ensiklopedi Nasional, Jilid 9, (Jakarta: PT Cipta Adi Darma Pustaka, 1990), h. 240.

${ }^{10}$ Samsul Rizal, Filsafat Pendidikan Islam Pendakatan Historis dan Peraktis (Jakarta: Ciputat Pers, 2002), h. 56.
} 
belajar mengajar, untuk mencapai tujuan pendidikan Islam yang diinginkan.

Kurikulum pendidikan Islam memiliki dasar yang kuat yaitu Alquran yang mana dijelaskan betapa pentingnya sebuah kurikulum dalam kemajuan pendidikan untuk mencapai kebahagiaan dunia dan akhirat yang terdapat pada surah al-Qashas ayat 77.

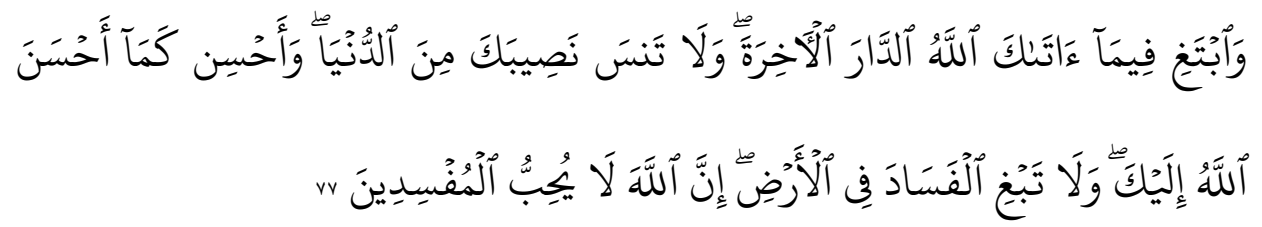

Artinya: "Dan carilah pada apa yang telah dianugerahkan kepadamu (kebahagiaan) negeri akhirat dan janganlah kamu melupakan kebahagiaanmu dari duniawi dan berbuat baiklah (kepada orang lain) sebagaimana Allah telah berbuat baik kepadamu dan janganlah kamu berbuat kerusakan di muka bumi, sesungguhnya Allah tidak menyukai orang-orang yang berbuat kerusakan. "11

Firman Allah di atas menjelaskan bahwa pentingnya ilmu pengetahuan dan keterampilan yang kita miliki. Sebagai makhluk ciptaannya dengan pengetahuan, keterampilan dan sikap yang baik, maka kita akan menjadi bahagia dan tidak melakukan kerusakan di muka bumi ini. Dengan demikian kurikulum yang berisi rancangan materi yang didukung komponene kurikulum yang lain harus mempunyai kualitas yang baik sesuai dengan tujuan pendidikan baik pendidikan nasional maupun pendidikan Islam.

Antara kurikulum pendidikan nasional dan kurikulum pendidikan Islam tidak ada perbedaan bahkan saling melengkapi satu sama lainnya tergantung pada lembaga masing-masing yang menjalankannya. Kalau melihat pengertian kurikulum di atas, tentu perlu dilakukan peninjauan kembali tentang inovasi kurikulum yang cocok di Madrasah Aliyah Darul Ihsan Samarinda, apakah sudah terkoordinir dengan baik atau perlu adanya perubahan-perubahan ke arah

\footnotetext{
${ }^{11}$ Departemen Agama RI, Terjemah Al-Qur`an, (Jakarta: Yayasan Penyelenggaraan Penterjemah Al-Qur`an, 1978), h. 622.
} 
perbaikan, sebab menurut Nasution kurikulum dipandang sebagi suatu rencana yang disusun untuk melancarkan proses belajar mengajar di bawah bimbingan dan tanggung jawab lembaga pendidikan serta staf pengajarnya. ${ }^{12}$

Kurikulum adalah salah satu instrumen yang menentukan proses belajar mengajar. Tanpa kurikulum yang baik, tujuan pendidikan sekolah tidak akan tercpai. Pelaksanaan kurikulum idealnya mampu diselesaikan dengan situasi dan kondisi yang ada pada suatu tempat.

Pelaksanaan teknis dalam sebuah lembaga pendidikan, proses belajar mengajar, evaluasi kemajuan murid, cara mengelola tenaga pengajar, dan berbagai kebijakan lainnya harus tercakup dalam kurikulum. Seperti dikatakan oleh J. Lioyd Trump dan Delams F dalam bukunya Scool Curriculum Improcement 1973, yang dikutip oleh Nasution adalah sebagai berikut:

Dalam kurikulum juga termasuk metode belajar mengajar, cara mengevaluasi dan penyeluhan, supervisi dan adminitrasi dan hal-hal struktur mengenai waktu, jumlah ruangan serta kemungkinan adanya pilihan mata pelajaran. ${ }^{13}$

Dari pernyataan di atas, jelas bahwa kurikulum adalah bahan acuan bagi lembaga pendidikan pada umumnya dan pendidik pada khususnya dalam pelaksanaan proses belajar mengajar, keberhasilan suatu kurikulum tergantung lembaga pendidikan yang menyiapkan kurikulum dan guru sebagai pelaksana dan sekaligus sebagai komponen kurikulum.

Dari uraian di atas mengenai pengertian kurikulum dapat ditarik benang merahnya, bahwa pada hakekatnya kurikulum tersebut merupakan:

a. Proses belajar mengajar yang terangkum dalm rencana pelajaran berisikan materi atau bahan pelajaran yang harus ditempuh dan dipelajari oleh siswa untuk memperoleh sejumlah pengetahuan. Kurikulum sebagai rencana pembelajaran dalam hal ini disediakan program pendidikan agar siswa melakukan kegiatan belajar, sehingga

\footnotetext{
${ }^{12}$ Nasution, Kurikulum dan Pengajaran, (Jakarta: Bina Aksara, tt), h. 5.

${ }^{13}$ Nasution, Asas-asas Kurikulum, (Bandung: Bumi Aksara, 1994), h. 13.
} 
terjadi perkembangan tingkah laku siswa. Sesuai dengan tujuan pendidikan dan pembelajaran.

b. Kurikulum merupakan serangkian pengalaman belajar dengan pengalaman belajar, maka siswa memiliki pengetahuan dan keterampilan serta dapat mengamalkan dalam kehidupan sehari-hari baik dalam keluarga, maupun masyarakat.

c. Dengan demikian secara sederhana pengertian kurikulum dapat didefinisikan sebagai suatu rencana pelajaran yang harus ditempuh dalam proses belajar mengajar untuk mendapatkan pengetahuan, pengalaman dengan cara sistematis dapat diterima oleh anak didik dengan maksud untuk mencapai tujuan pendidikan.

\section{Tujuan Kurikulum}

Berdasarkan tujuan kurikulum, mulai dari tujuan pendidikan nasional, tujuan lembaga pendidikan, tujuan mata pelajaran sampai pada tujuan pokok bahasan atau sub pokok bahasan, ${ }^{14}$ sebelum menyusun dan menentukan isi kurikulum, dan strategi pelaksanaan kurikulum, penilaian serta evaluasi kurikulum. Maka perlu dirumuskan terlebih dahulu tujuan kurikulum.

Tujuan kurikulum pendidikan nasional sama dengan tujuan pendidikan nasional, yaitu :

"Pendidikan nasional berfungsi mengembangkan kemampuan dan membentuk watak dan peradaban bangsa yang bermantabat dalam rangka mencerdaskan kehidupan bangsa, bertujuan untuk berkembangnya potensi peserta didik agar menjadi manusia yang beriman dan bertaqwa kepada Tuhan Yang Maha Esa berakhlak mulia, sehat berilmu, cakap, kreatif mandiri dan menjadi warga yang demokratis serta tanggung jawab." 15 2004), h. 22.

${ }^{14}$ Dakir, Perencanaan dan Pengembangan Kurikulum, (Jakarta : Reinika Cipta,

${ }^{15}$ Undang-Undang Sistem Pendidikan Nasional, (Bandung : Citra Negara, 2003), h. 7 . 
Menurut Undang-undang Sisdiknas Bab II ayat 3 th. 2003, penekanannya pada falsafah bangsa. Kurikulum harus memperhatikan dan mengembangkan falsafah bangsa agar dapat memelihara keutuhan nasional dengan memiliki ilmu, kreatif dan mandiri. Maka, dalam pembangunan bangsa akan cepat maju serta pembangunan sumber daya manusia tidak tertinggal dengan negara lain.

Untuk menunjang tujuan jangka panjang pembangunan Indonesia, terutama melalui peningkatan kualitas sumber daya manusia, karena pendidikan dipandang sebagai human invesmant, yakni sumber daya manusia yang akan menentukan keberhasilan pembangunan. Pembangunan manusia seutuhnya dan seluruh masyarakat untuk mewujudkan masyarakat adil makmur yang merata material dan spiritual.

Makna dan hakekat tersebut harus tercermin dalam tujuan kurikulum nasional sehingga menghasilkan sumber daya manusia yang memiliki potensi untuk melaksanakan pembangunan nasional.

Selain tujuan nasional, tujuan lembaga pendidikan juga perlu diperhatikan. Tujuan lembaga pendidikan ditentukan lembaga pendidikan itu sendiri. Dan tujuan lembaga pendidikan tinggi tidak sama dengan tujuan kurikulum yang ditentukan oleh lembaga pendidikan dasar, menengah, dan atas. Dalam pendidikan tinggi ini tujuannya adalah :

a. Menyiapkan peserta didik untuk menjadi anggota masyarakat yang memiliki kemampuan akademik dan atau menciptakan ilmu pengetahuan, teknologi dan kesenian.

b. Mengembangkan dan menyebarluaskan ilmu pengetahuan dan atau kesenian serta mengupayakan penggunaannya untuk meningkatkan taraf hidup masyarakat dan memperkaya kebudayaan nasional. ${ }^{16}$

Dengan menyiapkan peserta didik untuk menjadi masyarakat yang memiliki kemampuan akademik, menciptakan ilmu pengetahuan teknologi.

\footnotetext{
${ }^{16}$ Dakir, Perencanaan..., h. 10.
} 
Perlunya diperhatikan kondisi lingkungan terutama daerah kabupaten yang mempunyai otonomi daerah, maka sebuah lembaga pendidikan tinggi menyiapkan materi yang sesuai dengan kebutuhan anak dan masyarakat sekitar. Mengingat daerah kabupaten masih memerlukan pendidikan tinggi yang mempunyai kualitas yang memadai sebagai pembangunan sumber daya manusia di daerah tersebut.

Selain tujuan kurikulum di atas, maka yang perlu diperhatikan pelaksanaan kurikulum dalam pelaksanan kurikulum anak didik sebagai subyek dari pelaksanaan kurikulum, yang ada di sekolah tinggi ilmu tarbiyah Ibnu Rusyd diharapkan mampu untruk menyerap materi yang dibeikan. Tidak hanya pada tataran internalisasi nilai, tetapi teraplikasikan dalam hidup sehari-hari. Sesuai dengan kurikulum berbasis kompetensi yang menginginkan mahasiswa mnguasai materi dan memiliki kompetensi, karena tujuan kurikulum pendidikan adalah untuk anak didik. Oleh karena itu dalam merumuskan kurikulum perlu memperhatikan kebutuhan anak didik, terutama kemampuan anak, minat dan perhatian, dan sikap prilaku serta ciri kepribadian anak didik merupakan demensi-demensi penting untuk diperhatikan.

Menurut S. Nasution, yang dimaksud dengan tujuan pendidikan kurikulum itu adalah " "Segala tujuan kurikulum lainnya harus sesuai dengan tujuan pendidikan nasional, harus merupakan langkah dan sumbangan ke arah perwujudannya."17

Secara garis besar, tujuan kurikulum adalah : "Goals represent the broaddest or most general level at which education purpoles are developped." 18 Maksudnya adalah tujuan kurikulum untuk memperluas dan meperbesar tingkah dalam tujuan pendidikan yang dikembangkan.

${ }^{17}$ S. Nasution, Pengembangan Kurikulum, (Bandung: Aditia Bakti, 1981), h. 49.

${ }^{18}$ Jemes A, Beane, et.al, Kurikulum Planning and Developmen, (New York,tt.), h. 115 . 


\section{E. Fungsi Kurikulum}

Dalam proses belajar jelas kedudukan kurikulum sangat penting, karena dengan kurikulum maka anaka sebagai individu yang berkembang akan mendapatkan manfaat. Namun di samping anak, maka kurikulum juga berfungsi bagi para pendidik dalam melaksanakan proses belajar mengajar dengan maksud untuk mencapai tujuan pendidikan pengajaran, sebagai mana dikatakan oleh H. Ali Syaifullah, yaitu, "Fungsi adalah tiada lebih merupakan alat sarana untuk mencapai tujuan pengajaran."19

Selain itu, kurikulum sangat penting dan memberikan kemudahan dalam pengajaran sehingga pengajaran mempunyai makna dan bertujuan. Untuk itu, pengajaran harus direncanakan untuk mempermudah pembelajaran agar menjadi lebih bermakna.

Kurikulum sebagai tolak ukur yang dapat membentuk manusia berkualitas sesuai dengan fungsinya, antara lain :

a. Fungsi kurikulum dalam rangka pencapaian tujuan pendidikan.

Dalam definis kurikulum yang sudah dikemukakan, dapat disimpulkan bahwa kurikulum pada dasrnya merupakan suatu alat atau usaha untuk mencapai tujuan pendidikan. Tujuan pendidikan dapat dijabarkan dari tujuan tertinggi, yaitu tujuan pendidik terakhir yang akan dicapai yang disebut tujuan pendidikan nasional sampai pada tujuan yang terendah yaitu tujuan yang akan dicapai setelah kegiatan belajar mengajar.

Dari tujuan pendidikan tersebut, harus dicapai secara bertingkat dan kesemuanya saling mendukung. Kurikulum sebagai alat atau jembatan untuk mencapai tujuan.

b. Fungsi kurikulum bagi peserta didik.

Dalam pendidikan, anak didik merupakan subjek dan objek. Oleh karena itu, tanpa anak didik maka tujuan pendidikan tidak akan tercpai. Dalam hal ini kurikulum harus benar-benar diperlukan oleh peserta didik. h. 19 .

${ }^{19}$ Ali Syaifullah, Pengembangan Kurikulum, (Surabaya: Usaha Nasional, 1982), 
Menurut Samsul Nizar, peserta didik adalah : "Manusia yang memiliki kebutuhan baik yang menyangkut kebutuhan jasmani maupun rohani yang harus dipenuhi." 20

Dengan adanya kurikulum yang dibutuhkan maka proses belajar mengajar akan berjalan dengan baik, dan peserta didik mendapat sejumlah pengalaman baru yang kelak di kemudian hari dapat dikembangkan seirama dengan perkembangan peserta didik.

Untuk tingkat pendidikan tinggi peserta didik atau mahasiswa yang merupakan orang dewasa yang belajar untuk mendapatkan jenjang pendidikan lebih tinggi, dan mencapai kesarjanaannya, maka kurikulum yang disajikan berbeda dengan anak sekolah dasar, SMP dan SMA. Selain kemampuan akademik juga harus memiliki pola pikir yang sesuai dengan tingkat usia dan perkembangannya.

Peserta didik atau mahasiswa harus berperan aktif karena pendidik di sini hanya membimbing dan mengarahkan kepada hal-hal yang tidak diketahui peserta didik. Dengan kata lain pendidik sebagai motivator atau mediator. Kurikulum hendaknya tidak berorientasi pada tujuan saja, melainkan juga bagaimana siswa belajar.

Maka, pemahaman mengenai inovasi kurikulum akan sangat membantu penerapan kaidah-kaidah pembelajaran pendidikan. Inovasi kurikulum tidak dapat dipisahkan dari keberhasilan dalam pendidikan. Maju mundurnya pendidikan bergantung sejauhmana pemahaman guru dalam melaksanakan tugasnya di sekolah termasuk pada pemahaman kurikulum. Masalah inovasi kurikulum berkaitan dengan azas relevansi seperti epistimologis, psikologis dan sosial.

Ternyata munculnya inovasi sangat beragam, menurut Hamalik yang dikutif oleh Udin Syaefuddin, bahwa mengenai inovasi ini menjelaskan bahwa: 1) ada inovasi yang dikembangkan untuk menjawab

${ }^{20}$ Samsul Rizal, Filsafat..., h. 48. 
permasalahan relevansi seperti muatan local dalam kurikulum, 2) ada inovasi yang diarahkan untuk menjawab tantangan pemerataan pendidikan, 2) inovasi lebih menitik beratkan pada system, dan 4) inovasi yang berkaitan pada misi utamanya adalah menjawab permasalahan efisiensi pendidikan. $^{21}$

\section{F. Simpulan}

Inovasi kurikulum di Madrasah Aliyah (MA) Darul Ihsan Samarinda yaitu berupa: a) mengembangkan rencana inovasi kurikulum dengan segenap komponen madrasah yang ikut berpartisipasi, landasan inovasi kurikulumnya berupa budaya setempat dan kemajuan ilmu pengetahuan dan teknologi, b) inovasi tujuan kurikulum yang memadukan tujuan madrasah dan tujuan pemerintah/nasional, c) inovasi bahan ajar yang menyesuaikan visi dan misi sekolah sehingga dapat dicanangkan motode pembelajaran yang kontekstual, d) pemanfaatan media seperti OHP proyektor dan laptop saat mengajar, laboratorium komputer pada saat pelajaran praktek computer dan lainnya, e) penyusunan sistem evaluasi yang disesuaikan dengan program madrasah dan pemerintah, f) inovasi ekstrakurikuler atau pengembangan diri berupa maulid al- habsyi, rebana, seni kaligrafi, Arabic club, English club, bimbingan baca alQur'an, TIK, dan kelompok olahraga, seluruh merupakan program unggulan madrasah, dan terakhir g) inovasi muatan lokal yang diprogramkan agar sesuai dengan keunggulan madrasah berupa semua pelajaran pondok seperti: ilmu fiqih, tauhid, hadits, akhlak, faraidh, tafsir, nahwu shorf, tarikh, khot, ushul fiqh, dan pelajaran kitab kuning.

\section{G. Saran-Saran}

Hasil penelitian ini masih merupakan kajian dari 1 sekolah yaitu Madrasah Aliyah Darul Ihsan Samarinda, tentu akan berbeda dengan madrasah lain dalam mengembangkan kurikulumnya. Sehingga bagi peneliti lain ada

\footnotetext{
${ }^{21}$ Udin Syaefudin Sa’ud, Inovasi..., h. 87-87.
} 
Muhammad Rasyidi: Inovasi Kurikulum di Madrasah Aliyah

kesempatan untuk meneliti di madrasah lain sehingga dapat menjadi perbandingan dalam perkembangan kurikulum khususnya untuk tingkatan Aliyah. 


\section{Daftar Pustaka}

A, Beane, Jemes et.al. Kurikulum Planning and Developmen. New York,tt.

Dakir. Perencanaan dan Pengembangan Kurikulum. Jakarta : Rineka Cipta, 2004.

Departemen Agama RI. Terjemah Alquran. Jakarta: Yayasan Penyelenggaraan Penterjemah Alquran, 1978.

Ensiklopedi Nasional. Jilid 9. Jakarta: PT Cipta Adi Darma Pustaka, 1990.

Idi, Abdullah. Pengembangan Kurikulum Teori dan Praktek. Jakarta: Gaya Media,1999.

Muhajir, Noeng. Metodologi Penelitian Kualitatif. Yogyakarta: Rake Sarasin, 1988.

Nasution, S. Pengembangan Kurikulum. Bandung: Aditia Bakti, 1981.

Asas-asas Kurikulum. Bandung: Bumi Aksara, 1994.

Nasution. Kurikulum dan Pengajaran. Jakarta: Bina Aksara, tt.

Rizal, Samsul. Filsafat Pendidikan Islam Pendakatan Historis dan Peraktis. Jakarta: Ciputat Pers, 2002.

Singarimbun, Masri, Sofian Effendi (Ed). Metode Penelitian Survei. Jakarta: LP3ES, 1995.

Syaefudin Sa’ud, Udin. Inovasi Pendidikan. Bandung: Alfabeta, 2011. Inovasi Pendidikan. Bandung: Alfabeta, 2011.

Syaifullah, Ali. Pengembangan Kurikulum. Surabaya: Usaha Nasional, 1982.

Syaodih Sukmadinata, Nana. Pengembangan Kurikulum Teori dan Praktek. Bandung: PT. Remaja Rosdakarya, 2013.

Undang-Undang Sistem Pendidikan Nasional. Bandung: Citra Negara, 2003.

Zuriah, Nurul. Metodologi Penelitian Sosial Dan Pendidikan; Teori Dan Aplikasi. Jakarta: Bumi Aksara, 2006. 
Muhammad Rasyidi: Inovasi Kurikulum di Madrasah Aliyah

Al Qalam: Jurnal Ilmiah Keagamaan dan Kemasyarakatan

Vol. 13, No. 1, Januari-Juni 2019 